IJBPAS, October, 2020, 9(10): 2691-2696

ISSN: 2277-4998

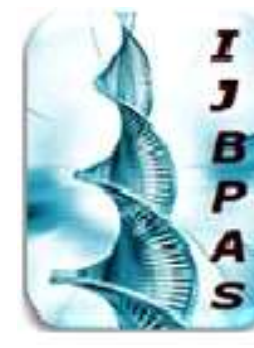

International Journal of Biology, Pharmacy and Allied Seiences (IJBPAS)

'A B ridge Betusen Caboratory and Q Qndor'

WwW.ijbpas.com

ANTIBACTERIAL EFFICACY OF MENTHOL IN A COMMERCIALLY AVAILABLE MOUTH FRESHENER

\title{
SYAM $\mathbf{S}^{1^{*}}$ AND MAHESWARI TNU ${ }^{2}$
}

1: PG Student, Department of Oral Medicine and Radiology, Saveetha Dental College, Saveetha Institute of Medical \& Technical Sciences, Chennai

2: Prof. \& Head of Admin., Department of Oral Medicine and Radiology, Saveetha Dental College, Saveetha Institute of Medical \& Technical Sciences, Chennai

*Corresponding Author: Syam S: E Mail: shilpaskottoor@gmail.com

Received 11 ${ }^{\text {th }}$ Feb. 2020; Revised $8^{\text {th }}$ March 2020; Accepted $11^{\text {th }}$ April 2020; Available online $1^{\text {st }}$ Oct. 2020

https://doi.org/10.31032/IJBPAS/2020/9.10.5225

ABSTRACT

Aim: In this study we aim to assess the antibacterial effect of menthol in a commercially available mouth freshener.

Materials and Methodology: Instantly dissolving breath strips were placed on the dorsum of the tongue and saliva samples were collected from twelve patients. Colony forming units (CFU) per $\mathrm{mL}$ saliva was counted both before and after the use of mouth freshener.

Results: The mean value of CFU / $\mathrm{mL}$ in saliva after the use of mouth freshener was lesser than the value before the use of mouth freshener

Conclusion: Menthol shows moderate antibacterial efficacy in the tested mouth freshener. Hence Synthetic antibacterial agents like Triclosan and Triclocarban which have harmful effects can be replaced with menthol in oral care products like mouthwashes, dentifrices, mouth fresheners.

Keywords: Menthol, Antibacterial, Antimicrobial, Mouth freshener, Mentha piperita INTRODUCTION

Essential oils generally obtained from spices, hemiterpenes, monoterpenes aromatic herbs, fruits, and flowers majorly sesquiterpens, menthol being one such constitute terpenoids present as monoterpene $[\mathbf{1 , 2}]$. It is a known fact that 
many of the terpenes can act against a variety of microbes including gram positive and negative bacteria and fungi and hence their antibacterial properties have been utilized in a wide array of commercial products like antiseptics, food preservatives, dental root canal sealers and mouth fresheners $[3,4]$. The antibacterial effect of essential oils and their monoterpenoid components such as menthol is generally explained by their toxic effects on the bacterial cell membrane structure and function $[5,6]$. Monoterpenes rapidly separate from an aqueous phase into membranes due to their lipophilicity. This results in expansion of membranes, increased membrane permeability, inhibition of respiration and altered ion transportation processes [7]. Antibacterial effect of menthol may result, at least partially, from changes in membrane permeability and intracellular material leakage due to a variation in the lipid fraction of the microorganism plasma membrane. This effect seems to be dependent on the net surface charge and lipid composition of the microbial cell membrane besides the characteristics of menthol [8]. Essential oils and their constituents alone cannot replace antibiotics but they can intensify or strengthen the antibiotic action [9].
Menthol is a primary constituent of a medicinally important plant Mentha piperita L. belonging to the family Lamiaceae. It was cultivated by the ancient Egyptians as documented in the thirteenth century pharmacopoeia of Iceland and now cultivated throughout all regions of the world. Menthol is the substance responsible for imparting the characteristic flavor and aroma to the mints and mint containing products [10]. Widespread usage of antibiotics has led to the serious issue of microbial resistance and a possible solution to this would be to switch to herbal(XI) and plant derived ingredients like menthol for antimicrobial effects. Mouth fresheners are used in various forms to mask halitosis or malodor. In addition to this several mouth fresheners claim to have antibacterial effect in the oral cavity. In this study we aim to assess the antibacterial efficacy of menthol in a commercially available mouth freshener.

\section{MATERIALS AND METHODS}

Patients between eighteen and thirty five years of age who reported to the outpatient department of a dental hospital were randomly chosen. Approval was obtained from the research \& ethics committee of the institution. Inclusion criteria were patients with generalized chronic gingivitis. Gingival status of the patients were assessed using the 
Gingival Index (American Academy of Periodontology) and those with a score of 1 or $>1$ were included in the study. A total of twelve patients were thus selected for the study. Informed consent was obtained from all the participants. Other inclusion criteria were individuals with no recent use of antibiotic or antibacterial mouthwash in the past one month and no associated comorbidities. Individuals with prosthodontics appliances and with a history of recent treatment (3 months) with antibiotics or antimicrobials were excluded from the study.

Patients were explained about the procedure and consent obtained. All patients were given distilled water to rinse their mouth after which saliva samples were collected. The mouth freshener under study available as instantly dissolving breath strips were placed on the dorsum of the tongue. After 3 minutes again saliva samples were collected from the patients. Saliva was diluted using distilled water upto a dilution factor of 1:80. All the samples were smeared to brain-heart infusion agar and incubated at $37^{\circ} \mathrm{C}$ for 24 hours. The colony forming units (CFU) were counted in both before and after salivary samples for all patients.

\section{RESULTS}

A Clustered bar chart was plotted for each patient with the corresponding values of $\mathrm{CFU} / \mathrm{mLin}$ saliva samples obtained before and after use of mouth freshener (Figure 1). Also Means of $\mathrm{CFU} / \mathrm{ml}$ in saliva samples collected before use of mouth freshener $\mu$ (BEFORE) plotted against the mean of $\mathrm{CFU} / \mathrm{mL}$ in saliva samples collected after the use of mouth freshener $\mu$ (AFTER) (Figure 2).

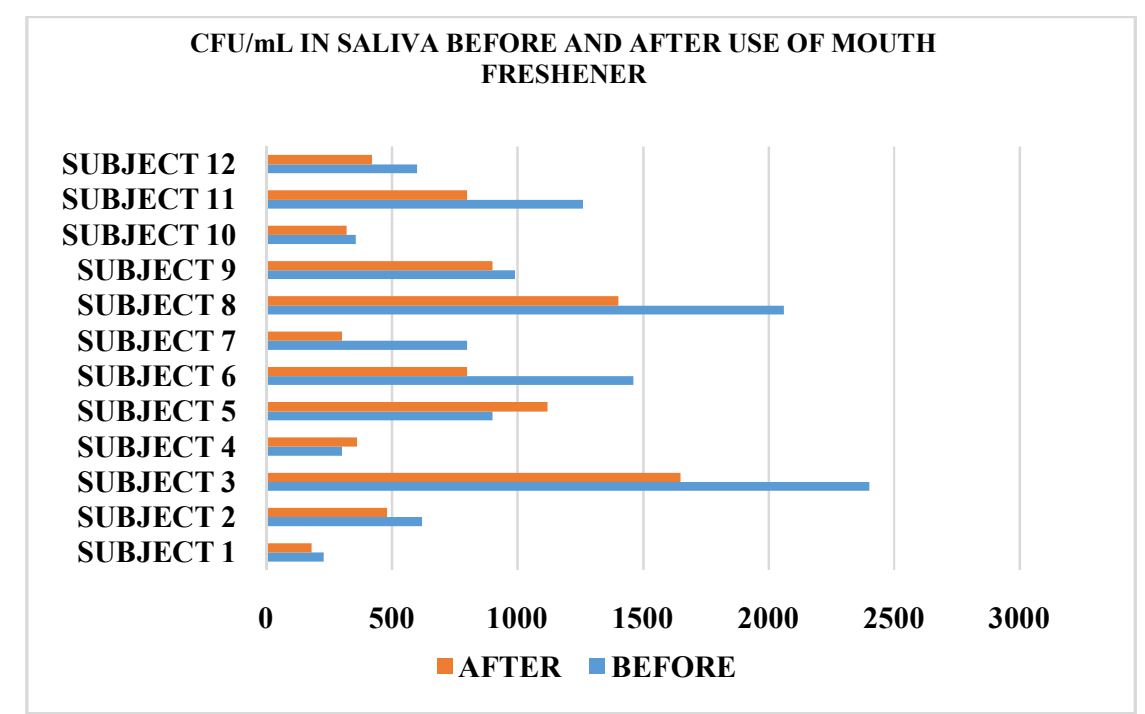

Figure 1: CFU/mLin saliva samples obtained before and after use of mouth freshener 


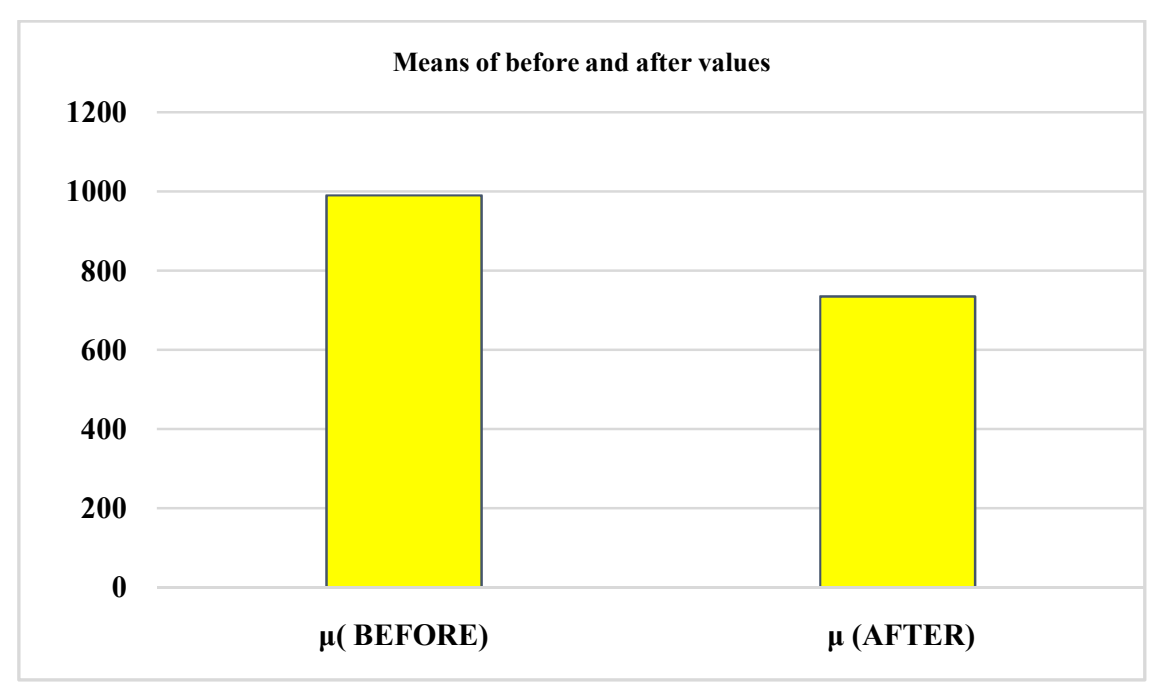

Figure 2: CFU/mL in saliva samples collected after the use of mouth freshener $\mu$

\section{DISCUSSION}

The results reveal that menthol present in the mouth freshener reduces the bacterial count in the oral cavity (mean difference of 255) and hence show a moderate antibacterial efficacy. In a previous study done to assess the antimicrobial activity of monoterpenes including menthol in vitro, it was found that menthol inhibits growth of both grampositive and gram-negative microbial strains and states specifically that menthol is toxic against $S$. aureus and E. coli [12]. In this study overall bacterial count reduction is studied and not the efficacy of menthol against specific bacterial strains or species. Another study that compared the antibacterial property of essesntial oil components in vitro revealed that menthol is less active against bacteria compared to peppermint oil and that Citrobacter $s p$. and Bacillus $s p$. were resistant to menthol [13]. In a study done on Mentha piperita oil using disc diffusion method, it was reported to have moderate antibacterial property against Staphylococcus aureus, Micrococcus flavus, Bacillus subtilis, Staphylococcus epidermidis, and Salmonella enteritides [14]. Another study which evaluated the action of common mouth washes on multidrug resistant biofilms reveals that menthol containing mouthwash had some activity against all bacterial strains except $S$. epidermidis and S. pyogenes [15]. Bacterial biofilms formation is a result of neglected dental hygiene that favours an environment for biofilm formation, thereby making the oral bacteria less susceptible to mouthwash or antiseptic formulations [1618]. Hence maintenance of good oral hygiene, which is expected to avoid the biofilm formation, is advised to ensure 
susceptibility of oral bacteria to mouthwashes and other oral care products [19].

\section{CONCLUSION}

Synthetic antibacterial agents like Triclosan [20] and Triclocarban which have harmful effects can be replaced by menthol in oral care products like mouthwashes, dentifrices, mouth fresheners to achieve antibacterial action without side effects .

\section{Conflict of interest}

The authors declare that they have no conflict of interests.

\section{REFERENCES}

[1] Kohlert C, van Rensen I, März R, Schindler G, Graefe EU, Veit M. Bioavailability and pharmaco-kinetics of natural volatile terpenes in animals and humans. Planta Med. 2000 Aug; 66(6): 495-505.

[2] Loza-Tavera H. Monoterpenes in essential oils. Biosynthesis and properties. Adv Exp Med Biol. 1999; 464: 49-62.

[3] Cowan MM. Plant products as antimicrobial agents. Clin Microbiol Rev. 1999 Oct; 12(4): 564-82.

[4] Ceylan E, Fung DYC. Antimicrobial Activity of Spices 1. J Rapid Methods Autom Microbiol. 2004 May 1; 12(1): $1-55$.

[5] Sikkema J, de Bont JA, Poolman B. Interactions of cyclic hydrocarbons with biological membranes. J Biol Chem. 1994 Mar 18; 269(11): 8022-8.

[6] Sikkema J, de Bont JA, Poolman B. Mechanisms of membrane toxicity of hydrocarbons. Microbiol Rev. 1995 Jun; 59(2): 201-22.

[7] M. Helander I, Alakomi H-L, LatvaKala K, Mattila-Sandholm T, Pol I, Smid E, et al. Characterization of the Action of Selected Essential Oil Components on Gram-Negative Bacteria. J Agric Food Chem 4635903595. 1998 Sep 1; 46.

[8] Trombetta D, Castelli F, Sarpietro MG, Venuti V, Cristani M, Daniele C, et al. Mechanisms of Antibacterial Action of Three Monoterpenes. Antimicrob Agents Chemother. 2005 Jun; 49(6): 2474-8.

[9] Horváth P, Koscova J. In vitro Antibacterial Activity of Mentha Essential Oils against Staphylococcus aureus. Folia Vet. 2017 Sep 1; 61.

[10] Bourwieg D, Pohl R. [Flavonoids from Mentha longifolia (author's transl)]. Planta Med. 1973 Dec; 24(4): 304-14.

[11] Hoque MM, Rattila S, Shishir MA, Bari ML, Inatsu Y, Kawamoto S. Antibacterial Activity of Ethanol Extract of Betel Leaf (Piper betle L.) Against Some Food Borne Pathogens. Bangladesh J Microbiol. 2012 Sep 5; 28(2): 58-63. 
[12] Trombetta D, Castelli F, Sarpietro MG, Venuti V, Cristani M, Daniele C, et al. Mechanisms of Antibacterial Action of Three Monoterpenes. Antimicrob Agents Chemother. 2005 Jun; 49(6): 2474-8.

[13] Pattnaik D, Vemulpad S, M Bapaji D, Kole C. Antibacterial and antifungal activity of aromatic constituents of essential oils. Microbios. 1997 Feb 1; 89: 39-46.

[14] Desam NR, Al-Rajab AJ, Sharma M, Mylabathula MM, Gowkanapalli RR, Albratty M. Chemical constituents, in vitro antibacterial and antifungal activity of Mentha piperita L. (peppermint) essential oils. J King Saud Univ - Sci [Internet]. 2017 Aug 2; Available from: http:// www. sciencedirect.com/science/article/pii/S1 $01836471730544 \mathrm{X}$

[15] Masadeh MM, Gharaibeh SF, Alzoubi KH, Al-Azzam SI, Obeidat WM. Antimicrobial Activity of Common Mouthwash Solutions on MultidrugResistance Bacterial Biofilms. J Clin Med Res. 2013 Oct; 5(5): 389-94.

[16] Hannig C, Basche S, Burghardt T, AlAhmad A, Hannig M. Influence of a mouthwash containing hydroxyapatite microclusters on bacterial adherence in situ. Clin Oral Investig. 2013 Apr 1; 17(3): 805-14.
[17] Williams MI. The antibacterial and antiplaque effectiveness of mouthwashes containing cetylpyri-dinium chloride with and without alcohol in improving gingival health. J Clin Dent. 2011; 22(6): 179-82.

[18] Moeintaghavi A, Arab H, Khajekaramodini M, Hosseini R, Danesteh H, Niknami H. In vitro antimicrobial comparison of chlorhexidine, persica mouthwash and miswak extract. J Contemp Dent Pract. 2012 Mar 1; 13(2): 147-52.

[19] Chandki R, Banthia P, Banthia R. Biofilms: A microbial home. J Indian Soc Periodontol. 2011; 15(2): 111-4.

[20] Dinwiddie MT, Terry PD, Chen J. Recent Evidence Regarding Triclosan and Cancer Risk. Int $\mathrm{J}$ Environ Res Public Health. 2014 Feb; 11(2): 220917. 